\title{
Water Quality of High-Altitude Lakes in the Sagarmatha (Everest) National Park, Nepal
}

\author{
Narayan Prasad Ghimire ${ }^{1 *}$, Pramod Kumar $\mathrm{Jha}^{1}$, Gianumberto Caravello ${ }^{2}$ \\ ${ }^{1}$ Central Department of Botany, Tribhuvan University, Kathmandu, Nepal; ${ }^{2}$ Department of Environment Health and Hygiene, Padova \\ University, Padova, Italy. \\ Email: "nghimire077@gmail.com
}

Received May $30^{\text {th }}, 2013$; revised June $30^{\text {th }}, 2013$; accepted July $8^{\text {th }}, 2013$

Copyright (C) 2013 Narayan Prasad Ghimire et al. This is an open access article distributed under the Creative Commons Attribution License, which permits unrestricted use, distribution, and reproduction in any medium, provided the original work is properly cited.

\begin{abstract}
The aim of this research was to analyze physical and chemical characteristics of high altitude lakes (Gokyo lake series, Imja lake, Pyramid lake) of the Sagarmatha National Park, Khumbu region located above $4500 \mathrm{~m}$ altitude. The lake water was studied for three years $(2008,2009$ and 2010) to compare the annual changes in the parameters. The findings created a database for present status of high land lakes of Nepal, which can be used for the management of lakes as well as to study the impact of tourism on water quality. The lake water quality in general still stands good in terms of standards for drinking water (WHO, Nepal standard) but degradation process has started. Total nitrogen in water samples was lower than the WHO standard but an increase in the nitrate nitrogen has been recorded. Similarly, total phosphorrous quality was also found increased.
\end{abstract}

Keywords: Physico-Chemical Characteristics; Water Quality; Tourism; High Altitudinal Lake

\section{Introduction}

The Sagarmatha National Park (SNP), established in 1976 and declared as a world Natural Heritage site in 1979, is located in the District of Solukhumbu, Nepal. The world's highest peak Mount Everest $(8848 \mathrm{~m})$ is located here. It is a popular eco-touristic destination for international community. Since the first ascent of Everest in 1953, around half a million trekkers (national \& international) visited the SNP. The number of tourists in the Khumbu region was 20 in 1964, which rose to peak number 32,123 in 2009 and 32,084 in 2010. In addition to international trekkers, a large number of people visit the SNP as porter and guide. On one side, there is economic gain through tourism in the Khumbu region; on the other it has produced some environmental concern [1]. Nepalese high altitude lakes are considered as relatively unpolluted and are oligotrophic [2]. Limnological studies in high altitude lakes of the Himalayas have been carried out [3-8] in the north west Indian himalaya. In Nepal, Loffer [9], Aizaki et al. [2] added useful information on the morphometry, physico-chemical and biological features, primary productivity, trophic status etc in the eastern Nepalese Himalayas. Loffer (1969) studied in 24 la-

${ }^{*}$ Corresponding author. kes between 4500 and $5600 \mathrm{~m}$ altitude in the Mount Everest area (Khumbu Valley), producing the first data on morphometry, chemistry and biology of these systems.

Nowadays, several studies have focused on the water chemistry of the highland [2,10-12]. They provided the data on morphometry, bathometry and pollution levels for management and protection of the high altitude wetlands of Nepal. Limnological survey (including chemistry, biology and sediment core studies) of lakes located between ca. 4500 and $5500 \mathrm{~m}$ a.s.l. has been performed since 1992 in the Kumbhu Valley, Nepal. Lake water chemical surveys reveal a constant increase of the ionic content of the lake water probably related to glacier retreat [13].

Gokyo lakes have been protected as Ramsar site since 2007, Imja lake has been taken as the risk of GLOFs. So, the main objective was to analyze the physio-chemical characters of the Gokyo lake series $\left(1^{\text {st }}, 2^{\text {nd }}, 3^{\text {rd }}\right.$ and $4^{\text {th }}$ Gokyo lake), Imja lake and Pyramid lake, which contribute to understand the present status of water of the different remote highland lakes in the Himalayan region. So that, these lakes can be protected or managed well. Thus, the parameters; temperature, $\mathrm{pH}$,conductivity, total dissolved solids, nitrogen and phosphorous were analyzed in different year $(2008,2009,2010)$ were analyzed to 
note the ecological status and annual changes in aquatic ecosystem of lake water in SNPBZ.

\section{Materials and Methods}

\subsection{Study Sites}

The Sagarmatha National Park (SNP) covers $1148 \mathrm{sq} \mathrm{km}$ area. This park lies about $140 \mathrm{~km}$ east of Kathmandu. It ranges between $27^{\circ} 30^{\prime} 19^{\prime \prime} \mathrm{N}$ and $27^{\circ} 06^{\prime} 45^{\prime \prime} \mathrm{N}$ latitude, $86^{\circ} 30^{\prime} 53^{\prime \prime} \mathrm{E}$ and $86^{\circ} 99^{\prime} 08^{\prime \prime} \mathrm{E}$ longitude. The park is characterized by rugged topography, altitude of park ranges from $2845 \mathrm{~m}$ at Jorsella to $8848 \mathrm{~m}$ at the top of the Mt. Everest (The World's highest mountain). It comprises three villages Development Committees (VDCs) namely Namche, Khumjung and Chaurikharka. The mountains of Sagarmatha National Park are geologically young and broken up by deep gorges and glacial valleys (Figure 1). Tourism is major source of economy of Khumbu region and many local residents still depend upon agro-pastoral activities. Tha population residing in the park is around 6000 and the area is inhabited mainly by Sherpa, followed by Tamang, Rai ethnic groups.

\subsection{Sample Collection}

Thirty three water samples from eleven (11) locations were collected and analyzed in three consecutive years 2008, 2009 and 2010. The criteria of selection of sampling points were based on outflow region of lakes.

\subsection{Field Measurements, Sample Preservation and Lab Analysis}

Parameters: temperature, $\mathrm{pH}$, conductivity, total dissolved solids (TDS), nitrogen and phosphorous were analyzed in different years $(2008,2009,2010)$ between MayJune to record the physical and chemical characters of different lakes to understand the status and annual changes in aquatic ecosystem of rivers water in SNPBZ during the hours 9:00 am to 11:00 am.

Water samples were collected from the lakes in acid rinsed polythene bottle of capacity $125 \mathrm{ml}$. Three drops of concentrated nitric acid were used to adjust the $\mathrm{pH}$ of the samples below 2 (acidic medium) to preserve it. The samples were brought to Kathmandu and analyzed in Ecology lab, Central Department of Botany, Tribhuvan University, Kathmandu. Nitrogen and phosphorous contents in lake water samples were measured by colorimetric method by making the standard curve method following Trivedy and Goel [14].

\subsection{Statistical Analysis}

Statistical analysis was completed using one way analysis of the variance (ANOVA) for compare mean by using the SPSS 16.0 version.

\section{Result and Discussion}

\subsection{Physical Parameters (Temperature, pH, Total Dissolved Solids and Conductivity)}

Water temperature varied from $8^{\circ} \mathrm{C}$ to $12^{\circ} \mathrm{C}$ with mean temperature $10.15^{\circ} \mathrm{C}$. The average temp was noted highest in Gokyo $3^{\text {rd }}$ Lake $\left(11.33^{\circ} \mathrm{C}\right)$, Gokyo $2^{\text {nd }}$ lake $\left(11.50^{\circ} \mathrm{C}\right)$ where as minimum temperature showed by Imja lake (near outlet) was $8.43^{\circ} \mathrm{C}$ (Table 1). This variation in temperature was due to altitudinal difference between different lakes and surround geology. All lakes are situated more than $4500 \mathrm{~m}$ altitude (Table 2). Similar trend of temperature (nearly range of $8^{\circ} \mathrm{C}$ ) was observed in all Gokyo series by Sharma et al. [12].

The temperature of Gokyo $3^{\text {rd }}$ lake was record $6^{\circ} \mathrm{C}$ and $7.5^{\circ} \mathrm{C}$ by $2^{\text {nd }}$ Gokyo lake. $3.7^{\circ} \mathrm{C}-5.5^{\circ} \mathrm{C}$ by Pyramid lake [10]. The average temperature $3^{\text {rd }}$ Gokyo lake was $10.4^{\circ} \mathrm{C}$ where as $6^{\circ} \mathrm{C}$ previous by Tartari et al. [10]. Similarly $2^{\text {nd }}$ lake Tartari et al reported $7.5^{\circ} \mathrm{C}$ where as the mean value was found $10.2^{\circ} \mathrm{C}$. Sharma et al. [12] also record the temperature of surface water of Gokyo $3^{\text {rd }}$ lake was $8^{\circ} \mathrm{C}$ and $2^{\text {nd }}$ lake, was $7^{\circ} \mathrm{C}$ for the surface water. Glacier retreat in the Everest region was found very rapidly (5.5 $8.7 \mathrm{~m} /$ annum) which accelerated (5.56 - $9.1 \mathrm{~m} / \mathrm{annum})$ during the 1997-2001 [15] which may be the Climate change [16]. So, there was found the increasing trend of temperature of the water bodies of SNPBZ. Minimum temperatures $\left(4^{\circ} \mathrm{C}\right.$ to $\left.16^{\circ} \mathrm{C}\right)$ were recorded in alpine lakes in Italy [17].

The $\mathrm{pH}$ values were noted between 7.0 - 8.1, which indicated well buffer capacity. The highest value was noted in Gokyo lake (8.1) where as lowest in Imja lake (7.0). But in some year some plots shows very high $\mathrm{pH}$ value, Gokyo lake in $2008(8.7)$, Gokyo $3^{\text {rd }}$ lake in 2008 (9.3). More than 8 value of $\mathrm{pH}$ was noted in 2008 in six samples (Table 3).

$\mathrm{pH}$ of lake water was found within the range between 6.0 to 8.0 in study year. $\mathrm{pH}$ value of $3^{\text {rd }}$ lake in 1998 was $7.2,2^{\text {nd }}$ lake was 7.3 , the lake above the pyramid ranged between 7.2 to 7.9 [10], where as the present study Gokyo $3^{\text {rd }}$ lake 7.8 , Gokyo $1^{\text {st }}$ lake 7.9 and Gokyo $2^{\text {nd }}$ lake 7.4. In case of streams, different streams showed the same range than the previous report, lobuche khola at Pheriche; 7.5 [10] where as the present study it was recorded the 7.2. Lami et al. [13] also recorded the $\mathrm{pH}$ range between 6.2 to 8.2 in the high altitude lake of Khumbu valley. Antoninetti et al. [18] also recorded the range between 7.4 to $8.2 \mathrm{pH}$ in the lake water of Khumbu himal area. For $\mathrm{pH}$ point view, the all water bodies are still good for drinking as well as other purpose. So, $\mathrm{pH}$ values were found in the decreasing trend (Figure 2). Although all the present data were found below the 


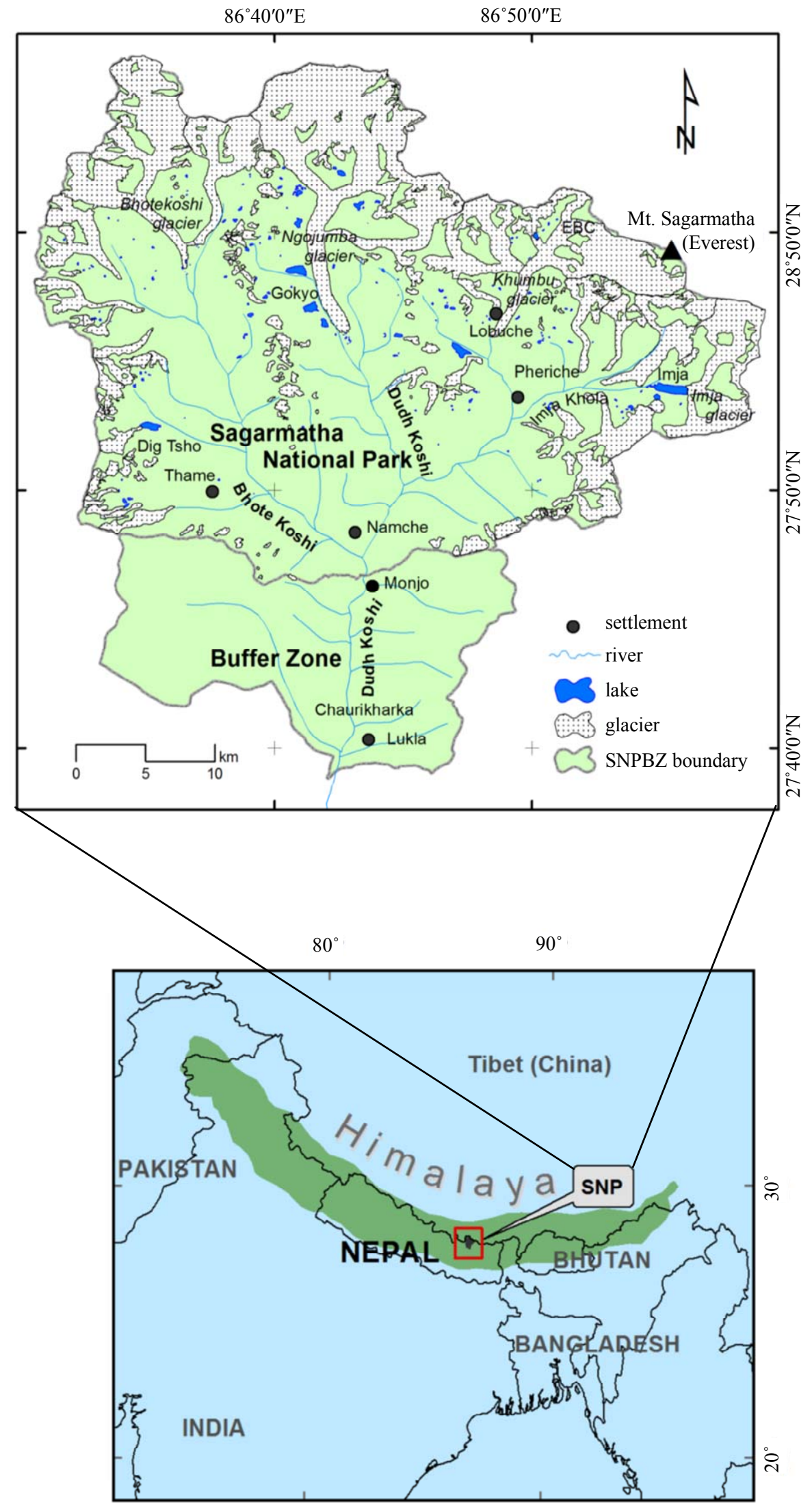

Figure 1. Location of Sagarmatha National Park in South Asia and position of lakes in the SNP. 
Table 1. Physical and chemical characteristics of water in different lakes in Sagarmatha National Park.

\begin{tabular}{|c|c|c|c|c|c|c|c|c|c|c|c|c|c|c|c|c|c|c|}
\hline \multirow{2}{*}{ S.N } & \multicolumn{3}{|c|}{ Temp $\left({ }^{\circ} \mathrm{C}\right)$} & \multicolumn{3}{|c|}{$\mathrm{pH}$} & \multicolumn{3}{|c|}{ TDS (ppt) } & \multicolumn{3}{|c|}{ Conductivity (mS) } & \multicolumn{3}{|c|}{$\mathrm{TN}-\mathrm{NO}_{3}(\mathrm{mg} / \mathrm{l})$} & \multicolumn{3}{|c|}{ TP-PO $4(\mathrm{mg} / \mathrm{l})$} \\
\hline & 2008 & 2009 & 2010 & 08 & 09 & 010 & 08 & 09 & 010 & 08 & 09 & 010 & 08 & 09 & 010 & 08 & 09 & 010 \\
\hline A22 & 9.5 & 10.3 & 7.6 & 8.6 & 7.1 & 8.3 & 0.02 & 0.02 & 0.06 & 0.03 & 0.03 & 0.09 & 1.25 & 0.72 & 1.03 & 0.09 & 0.14 & 0.61 \\
\hline A 23 & 11.2 & 10 & 8 & 7.7 & 7.5 & 6.5 & 0.02 & 0.01 & 0.02 & 0.03 & 0.02 & 0.03 & 0.86 & 0.87 & 1.4 & 0.28 & 0.14 & 0.03 \\
\hline A26 & 12.2 & 10.3 & 9.4 & 8.7 & 7.8 & 7.8 & 0.02 & 0.02 & 0.02 & 0.03 & 0.03 & 0.03 & 0.2 & 0.71 & 1.82 & 0.24 & 0.97 & 0.33 \\
\hline A 27 & 14.2 & 10.3 & 10 & 8.5 & 6.7 & 7 & 0.02 & 0.02 & 0.02 & 0.03 & 0.03 & 0.03 & 0.68 & 1.18 & 1.03 & 0.27 & 0.54 & 0.32 \\
\hline A 28 & 13.5 & 10.3 & 10.2 & 8.3 & 7.7 & 7.5 & 0.02 & 0.01 & 0.02 & 0.03 & 0.02 & 0.01 & 0.2 & 0.41 & 0.77 & 0.02 & 0.17 & 0.54 \\
\hline A 29 & 14.4 & 10 & 10 & 7.7 & 7.1 & 7.2 & 0.01 & 0 & 0 & 0.02 & 0.01 & 0.01 & 0.72 & 0.81 & 0.21 & 0.03 & 0.22 & 0.28 \\
\hline A 30 & 14.4 & 10.2 & 9.7 & 8.1 & 6.8 & 6.9 & 0.01 & 0.01 & 0.01 & 0.02 & 0.02 & 0.02 & 0.65 & 0.21 & 0.97 & 0.08 & 0.3 & 0.08 \\
\hline A 31 & 9.8 & 10.3 & 10.1 & 9.3 & 6.7 & 6.8 & 0.02 & 0.02 & 0.02 & 0.03 & 0.03 & 0.03 & 0.2 & 2.79 & 0.92 & 0.11 & 0.1 & 0.68 \\
\hline A58 & 4.5 & 10 & 10.8 & 7 & 6.7 & 7.3 & 0.01 & 0 & 0.02 & 0.01 & 0.01 & 0.03 & 0.72 & 0.15 & 0.01 & 0.39 & 0.12 & 0.4 \\
\hline A59 & 4.9 & 10.3 & 10.2 & 7.6 & 6.7 & 7.4 & 0.01 & 0 & 0.01 & 0.01 & 0.01 & 0.02 & 0.68 & 0.17 & 2.6 & 0.42 & 0.08 & 2.64 \\
\hline
\end{tabular}

Table 2. Description of the sampling sites in the Sagarmatha National Park.

\begin{tabular}{|c|c|c|c|c|}
\hline S. code & Name of Site & Latitude & Longitude & Altitude (m) \\
\hline A22 & Gorekshep lake & 27.98278 & 86.83073 & 5145 \\
\hline A23 & Between Pyramid and Gorekshep lake & NA & NA & 5100 \\
\hline A24 & Pyramid lake & 27.96185 & 86.81293 & 5053 \\
\hline A26 & $1^{\text {st }}$ lake of Gokyo (outlet) & 27.93088 & 86.70663 & 4661 \\
\hline $\mathrm{A} 27$ & $2^{\text {nd }}$ lake of Gokyo (outlet) & 27.94033 & 86.69785 & 4716 \\
\hline A28 & $3^{\text {rd }}$ lake of Gokyo outlet & 27.94887 & 86.7125 & 4720 \\
\hline A29 & $4^{\text {th }}$ lake Gokyo (mid of lake) & 27.971933 & 86.6866 & 4850 \\
\hline A30 & $4^{\text {th }}$ lake Gokyo (outlet) & 27.97383 & 86.6868 & 4860 \\
\hline A31 & $3^{\text {rd }}$ lake of Gokyo (inlet) & 27.95375 & 86.69333 & 4740 \\
\hline A58 & Imja lake near outlet & 27.89873 & 86.91375 & 5011 \\
\hline A59 & Imja lake outlet & 27.89967 & 86.90692 & 5007 \\
\hline
\end{tabular}

$\mathrm{NA}=$ Not available.

Table 3. Average value of lake water in 2008, 2009 and 2010 in the month of (May-June).

\begin{tabular}{|c|c|c|c|}
\hline Parameters & 2008 & 2009 & 2010 \\
\hline Temp $\left({ }^{\circ} \mathrm{C}\right)$ & $10.748^{\mathrm{a}} \pm 3.492$ & $10.239^{\mathrm{a}} \pm 0.177$ & $9.455^{\mathrm{a}} \pm 1.08$ \\
\hline $\mathrm{pH}$ & $8.047^{\mathrm{a}} \pm 0.719$ & $7.082^{b} \pm 0.414$ & $7.301^{\mathrm{b}} \pm 0.503$ \\
\hline Conductivity ( $\mathrm{mS})$ & $0.025^{\mathrm{a}} \pm 0.008$ & $0.021^{\mathrm{a}} \pm 0.008$ & $0.030^{\mathrm{a}} \pm 0.021$ \\
\hline TDS (ppt) & $0.016^{\mathrm{a}} \pm 0.005$ & $0.011^{\mathrm{a}} \pm 0.008$ & $0.020^{\mathrm{a}} \pm 0.015$ \\
\hline $\mathrm{TN}-\mathrm{NO}_{3}(\mathrm{mg} / \mathrm{lit})$ & $0.675^{\mathrm{a}} \pm 0.373$ & $0.739^{\mathrm{a}} \pm 0.767$ & $1.050^{\mathrm{a}} \pm 0.714$ \\
\hline TP-PO 4 (mg/lit) & $0.185^{\mathrm{a}} \pm 0.141$ & $0.276^{\mathrm{a}} \pm 0.264$ & $0.574^{\mathrm{a}} \pm 0.714$ \\
\hline
\end{tabular}


WHO standard.

The quality of total dissolved solids (TDS) was found between 0.01 to $0.03 \mathrm{ppt}$ (Table 1). In the first year (2008 May), all the samplings showed TDS between 0.01 and $0.02 \mathrm{ppt}$. In the next year it value ranged the same 0.00 to $0.02 \mathrm{ppt}$, where as in 2010, Goreskshep near lake near to Gorekshep settlement $(5100 \mathrm{~m})$ altitude showed 0.06 ppt (Table 1).

The average conductivity value was recorded 0.01 to $0.05 \mathrm{mS}$ (Table 3). Gorekshep lake showed the highest conductivity $0.05 \mathrm{mS}$ among other water bodies of the lake system. Imja lake and $4^{\text {th }}$ Gokyo lake recorded the lowest conductivity due to presence of low TDS and other compound. In 2010, (0.09 mS) conductivity was recorded in Gorekshep lake which also showed the highest TDS. Among the other lakes $2^{\text {nd }}$ lake Gokyo lake $(0.03 \mathrm{mS})$ in 2010 , Pyramid lake $(0.03 \mathrm{mS}), 1^{\text {st }}$ Gokyo lake $(0.03 \mathrm{mS}), 3^{\text {rd }}$ Gokyo lake $(0.03 \mathrm{mS})$, Imja lake (near outlet) $(0.03 \mathrm{mS})$ values of conductivity were recorded (Table 1). In average, the conductivity of water of water in different lakes were $0.025 \mathrm{mS}, 0.021 \mathrm{mS}$ and $0.03 \mathrm{mS}$ in 2008, 2010 and 2010 (Figure 3).

Conductivity and TDS of all the water samples of lakes were very low and did not show any significant change during the study period (Figures 3 and 4). TDS and conductivity data of lake in SNPBZ reveal that thses

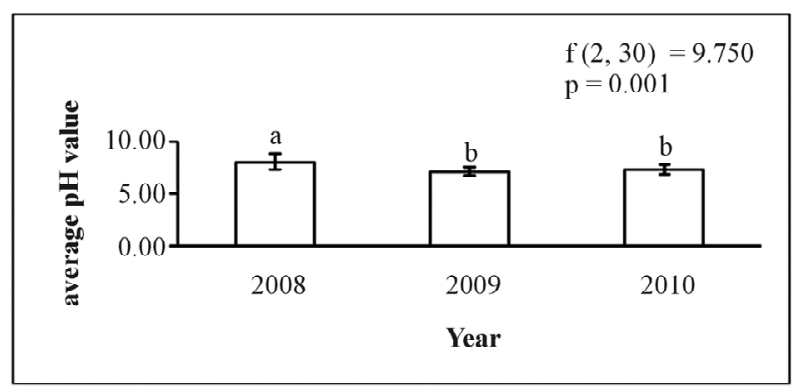

Figure 2. Average pH of water in lakes in 2008, 2009 and 2010. ${ }^{*} \mathrm{~F}=$ (degree of freedom beteween the group, within the group) (p=level of significance, $a, b, c$ represent the annual variation).

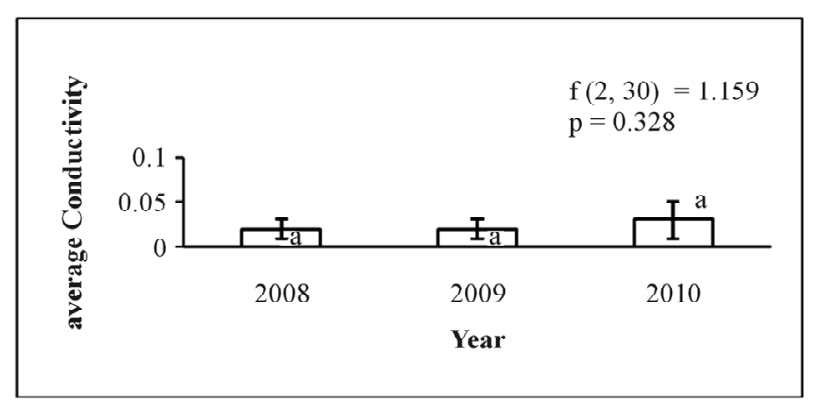

Figure 3. Average conductivity of lake water in 2008, 2009 and 2010. ${ }^{*} F=$ (degree of freedom beteween the group, within the group) ( $p=$ level of significance, $a, b, c$ represent the annual variation). water bodies are still unpolluted. 0.01 to $0.004 \mathrm{~s} / \mathrm{cm}$ by Gokyo lake series by Tartari et al. [10] and between 0.01 $\mathrm{mS}$ to $0.04 \mathrm{mS}$ were found in the Gokyo lake series in the present study (Tables $\mathbf{1}$ and 2).

Similarly result was found by earlier researchers (0.008 - $0.067 \mathrm{~s} / \mathrm{cm}$ by Lami et al. [13] for high altitude lakes of Khumbu valley, 0.011 to $0.51 \mathrm{~s} / \mathrm{cm}$ by Antoninetti et al. [18] for Khumbu lake water. 0.019 to 0.057 $\mathrm{s} / \mathrm{cm}$ in the streams of upper khumbu valley by Renold et al. [19]. The conductivity range in the alpine lakes in Italy was found between 0.01 to $0.17 \mathrm{~s} / \mathrm{cm}$ in Italy [17].

\subsection{Chemical Parameters}

\section{Nitrrate-Nitrogen (TN-NO $\left.{ }_{3}\right)$ and}

\section{Phosphate-Phosphorous (TP-PO ${ }_{4}$ )}

The average nitrate-nitrogen quality in lake water ranges between $0.29 \mathrm{mg} / \mathrm{l}$ and $1.30 \mathrm{mg} / \mathrm{l}$. lowest value $(0.29$ $\mathrm{mg} / \mathrm{l})$ was recorded in Imja lake water due to no sewage discharge and no any agricultural land around the lake (Figure 5). Very less amount of nitrate nitrogen was recorded due to presence of only natural nitrogen. Highest value of nitrate-nitrogen in $3^{\text {rd }}$ Gokyo lake was $1.30 \mathrm{mg} / \mathrm{l}$. This lake is very near to settlement and garbage pit as

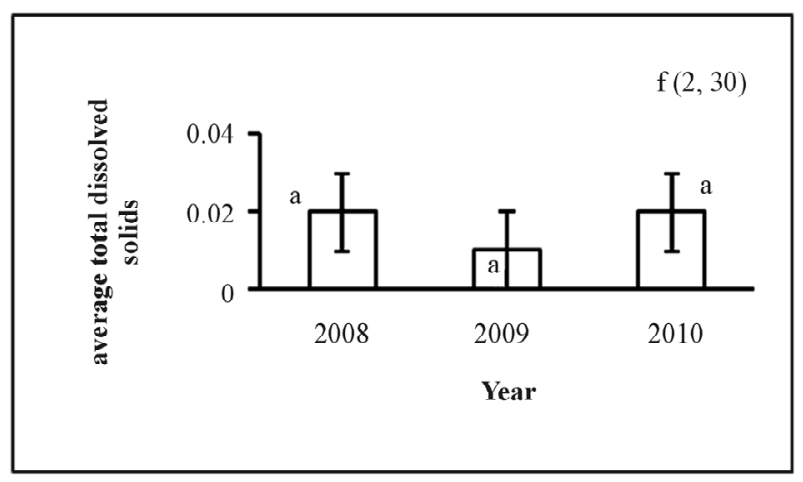

Figure 4. Average TDS in lake water in 2008, 2009 and 2010. ${ }^{*} \mathbf{F}=$ (degree of freedom beteween the group, within the group) ( $p=$ level of significance, $a, b, c$ represent the annual variation).

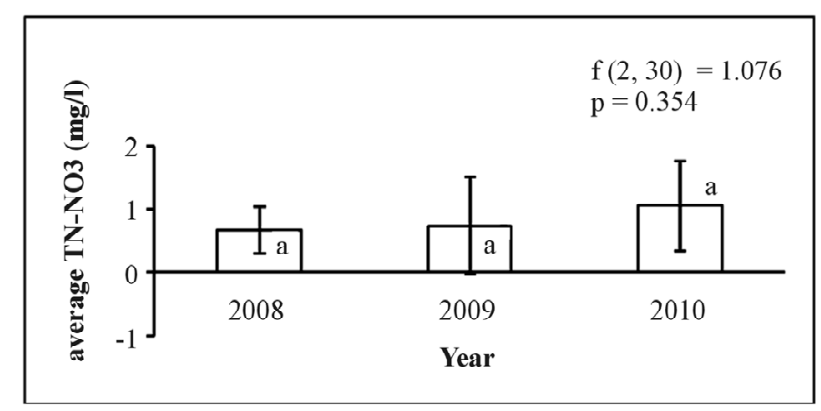

Figure 5. Average nitrogen in lake water in 2008, 2009 and $2010 .{ }^{*} \mathrm{~F}=$ (degree of freedom beteween the group, within the group) (p = level of significance, $a, b, c$ represent the annual variation). 
well as septic tank of toilets is very close to the Gokyo lake. Some variations were recorded in $\mathrm{TN}-\mathrm{NO}_{3}$ value in different sampling sites $2.79 \mathrm{mg} / \mathrm{l}$ in 2010 by $3^{\text {rd }}$ lake, $1.82 \mathrm{mg} / \mathrm{l}$ in $20091^{\text {st }}$ lake outlets (Tables 1 and 2). But, overall, nearly average value of nitrate-nitrogen was increasing in Gokyo lakes when compared with the earlier reported [10].

Total nitrogen as nitrate in the lake was recorded between $0.4 \mathrm{mg} / 1$ and $1.03 \mathrm{mg} / 1$. Imja lake (outlet), $4^{\text {th }}$ Gokyo lake showed higher value of $\mathrm{TN}-\mathrm{NO}_{3}$. Previously nitrate in Gokyo $3^{\text {rd }}$ lake $0.056 \mathrm{mg} / \mathrm{l}$ nitrate was recorded where as $0.21 \mathrm{mg} / \mathrm{l}$ as total nitrogen. Similarly, in $2^{\text {nd }}$ Gokyo lake, $0.065 \mathrm{mg} / \mathrm{l}$ as nitrate and $0.31 \mathrm{mg} / \mathrm{l} \mathrm{TN}$ were recorded by Tartari et al. [10] and 0.18 to $0.75 \mathrm{mg} / \mathrm{l}$ by Antoninetti et al. [18] for lake water but in the present study $0.86 \mathrm{mg} / \mathrm{l}$ average Nitrogen as nitrate was recorded (Table 3). Present result showed higher nitrate-nitrogen than the earlier reports. Pyramid lake showed $0.86 \mathrm{mg} / \mathrm{l}$ average nitrogen as nitrate where as $0.11 \mathrm{mg} / 1-0.301$ $\mathrm{mg} / \mathrm{l}$ nitrate-nitrogen were recorded between 1990-1997 by Tartari et al. [10]. Lami et al. [13] reported that TN was $0.12 \mathrm{mg} / 1$ to $0.75 \mathrm{mg} / \mathrm{l}$ with mean value was 0.29 $\mathrm{mg} / \mathrm{l}$ for high altitude lake but present study revealed that the average value of TN as nitrate was found $0.82 \mathrm{mg} / 1$ which is more than the maximum value reported earlier.

The averages phosphorous as phosphate was recorded between $0.18-1.05 \mathrm{mg} / \mathrm{l}$ in different lakes (Figure 6). The higher value of phosphorius were recorded as: $1^{\text {st }}$ Gokyo lake $(0.51 \mathrm{mg} / \mathrm{l}), 2^{\text {nd }}$ gokyo lake $(0.38 \mathrm{mg} / \mathrm{l})$, Imja lake $(1.05 \mathrm{mg} / \mathrm{l})$ where as the lower value recorded by $4^{\text {th }}$ Gokyo lake (0.18 mg/l), Pyramid lake (0.26 mg/l) (Table 2). In the first year (2008), lower amount of phosphorous was recorded $(0.02$ and $0.03 \mathrm{mg} / \mathrm{l})$ and higher were upto $0.42 \mathrm{mg} / \mathrm{l}$ in Imja lake, where as in 2009, minimum was upto $0.08 \mathrm{mg} / \mathrm{l}$ and maximum was $0.97 \mathrm{mg} / \mathrm{l}$ in $1^{\text {st }}$ Gokyo lake. In the final year (2010), the values ranged between 0.03 and $2.64 \mathrm{mg} / 1$. Highest value of phosphorous was found in Imja lake $(2.64 \mathrm{mg} / \mathrm{l})$ (Table 1). Hence little change was found from 2008 to 2010 at almost all the

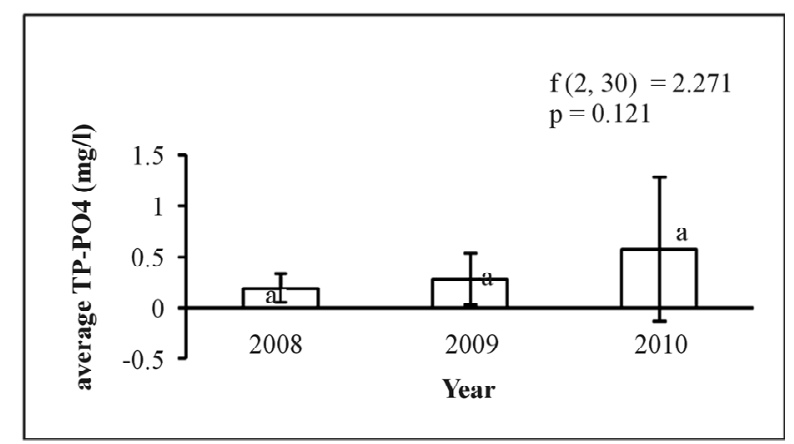

Figure 6. Average phosphorous of lake water in 2008, 2009 and $2010 .{ }^{*} F=$ (degree of freedom beteween the group, within the group) $(p=$ level of significance, $a, b, c$ represent the annual variation). sampling sites (Figure 6).

Lami et al. [13] analyzed the lake water chemistry and concluded that phosphorous contained lower than 0.005 $\mathrm{mg} / \mathrm{l}$ in more than $50 \%$ samples where as the present average phosphorous as phosphate value was found 0.345 $\mathrm{mg} / \mathrm{l}$. Antoninetti et al. [18] recorded between 0.002 to $0.011 \mathrm{mg} / \mathrm{l}$ in lake water of Khumbu Himal which was less than that obtained 2007 by our team. Comparatively there is a trend of increasing of phosphorous in water bodies. The annual variation also showed that there was increasing trend but all the values were found between the standard limits.

\section{Conclusion}

Changes in the value of $\mathrm{pH}$, increased quantity of TN$\mathrm{NO}_{3}, \mathrm{TP}-\mathrm{PO}_{4}$ were noted in the lakes in SNPBZ. There is increasing trend of anthropogenic activities that added pollutants. Human waste (toilet) disposed to the water bodies, different types of litter employed in the agriculture field, and human wastes (excreta) and solid waste disposal are major sources of nitrogen and phosphorous.

\section{Acknowledgements}

Thanks to HKKH Partnership Project for financial support to conduct this research, and to department of National Park and Wildlife Conservation and Sagarmatha National Park for permission to work in Sagarmatha National Park and Buffer Zone. Thanks are also due to Prof. A. Baroni and Prof. M. Boselli for encouragement.

\section{REFERENCES}

[1] G. U. Caravello, A. M. Boselli, P. Bertollo and A. Baroni, "Assessing Ecosystem Health: An Analysis of Tourism Related Change and Impact in Khumbu Valley," Ecoprint: An International Journal of Ecology, Vol. 14, No. 1, 2007, pp. 45-64.

[2] M. Aizaki, A. Terashima, H. Nakahara, T. Nishio and Y. Ishida, "Tropic Status of Tilitso, a High Altitude Himalayan Lake," Hydrobiologia, Vol. 153, No. 3, 1987, pp. 217-224. doi:10.1007/BF00007208

[3] G. Sars, "On the Crustacean Fauna of Central Asia. Pt. II Cladocera," Annals of Zoology of the Academy of Imperial Science of St. Petersburg, Vol. 8, No. 1, 1903, pp. 157-194.

[4] G. E. Hutchinson, "Limnological Studies in Indian Tibet," Internationale Revue der Gesamten Hydrobiologie, Vol. 35, No. 1-6, 1937, pp. 134-177.

[5] M. A. Khan and D. P. Zutshi, "Contribution to High Altitude Limnology of the Himalayan System. I. Limnology and Primary Productivity of the Plankton Community of Nilang Lake, Kashmir," Hydrobiologia, Vol. 75, 1980, pp. 102-112. doi:10.1007/BF00007422

[6] P. C. Sharma and M. C. Pant, "Species Composition of Zooplancton in Two Kumanu Himalayan Lakes (U.P. In- 
dia)," Archiv für Hydrobiologie, Vol. 102, No. 3, 1985, pp. 387-403.

[7] K. K. Vass, A. Wanganeo, H. S. Raina, D. P. Zutshi and R. Wanganeo, "Summer Limnology and Fisheries of High Mountain Lakes of Kashmir Himalayas," Archiv für Hydrobiologie, Vol. 114, No. 4, 1989, pp. 603-620.

[8] D. P. Zutshi, "Limnology of High Altitude Lakes of Himalayan Region," Verhandlungen des Internationalen Verein Limnologie, Vol. 24, 1991, pp. 1077-1080.

[9] H. Loffler, "High Altitude Lakes in Mt. Everest Region," Verhandlungen des Internationalen Verein Limnologie, Vol. 17, 1969, pp. 373-385.

[10] G. A. Tartari, G. Tartari and R. Mosello, "Water Chemistry of High Altitude Lakes in the Khumbu and Imja Kola Valleys (Nepalese Himalayas)," In: A. Lami and G. Giussani, Eds., Limnology of High Altitude Lakes in the Mt Everest Region (Nepal), Memorie delllstituto Italiano di Idrolnologia, Vol. 57, No. 1, 1998, pp. 51-76.

[11] P. Lacoul and B. Freedman, "Physical and Chemical Limnology of 34 Lentic Waterbodies along a Tropical-to-Alpine Altitudinal Gradient in Nepal," International Review on Hydrobiology, Vol. 90, No. 3, 2005, pp. 254-276. doi:10.1002/iroh.200410766

[12] C. M. Sharma, S., Sharma, S. Gurung, I. Juttner, R. M. Bajracharya and N. S. Pradhan, "Ecological Studies within the Gokyo Wetlands, Sagarmatha National Park, Nepal," In: P. K. Jha and I. Khanal, Eds., Contemporary Research in Sagarmatha (Mt. Everest) Region, Nepal: An Anthology, Nepal Academy of Science and Technology, Kathmandu, 2010, pp. 139-154.

[13] A. Lami, G. A. Tartari, S. Musazzi, P. Guilizzoni, A. Marchetto, M. Manca, A. Boggero, A. M. Nocentini, G.
Morbito, G. Tartari, L. Luzzella, R. Bertoni and C. Callieri, "High Altitude Lakes: Limnology and Paleolimnology," Mountains Witnesses of Global Changes, Elsevier, Amsterdam, 2007, pp. 155-170.

[14] R. K. Trivedy and P. K. Goel, "Chemical and Biological Methods for Water Pollution Studies," Environment Publication, Karad, 1986.

[15] J. Ren, D. Qin, S. Kang, S. Hou, J. Pu and Z. Jing, "Glacier Variations and Climate Warming and Drying in the Central Himalayas," Chinese Science Bulletin, Vol. 49, No. 1, 2004, pp. 65-69.

[16] J. D. Ives, "Global Warming - A Threat to Mount Everest?" Mountain Research and Development, Vol. 25, No. 4, 2005, pp. 391-394.

[17] R. Tiberti, G. A. Tartari and A. Marchetto, "Geomorphology and Hydrochemistry of 12 Alpine Lakes in Gran Paradiso National Park, Italy," Journal of Limnology, Vol. 69 , No. 2, 2010, pp. 242-256. doi:10.4081/jlimnol.2010.242

[18] M. Antoninetti, M. Pepe, G. Iabichino, C. De Vito and G. Tartari, "Environmental Information System of KhumbuHimal Areas," In: R. Baudo, G. Tartari and M. Munawar, Eds., Top of the World Environmental Research: Mount Everest-Himalayan Ecosystem, Backhuys Publishers, Leiden, 1998, pp. 263-284.

[19] B. Reynolds, A. Jenkins, P. J. Chapman and J. Wilkinson, "Stream Hydrochemistry of the Khumbu, Annapurna and Lantang Regions of Nepal," Top of the World Enviromental Research: Mount Everest-Himalayan Ecosystem, Backhuys Publishers, Leinden, 1998, pp. 123-140. 